\begin{tabular}{|l|l|}
\hline $\begin{array}{l}\text { 2. To: (Receiving Organization) } \\
\text { Distribution }\end{array}$ & $\begin{array}{l}\text { 3. From: coriginating Organization) } \\
\text { WTFP Engineering Support } \\
\text { Group }\end{array}$ \\
\hline $\begin{array}{l}\text { 5. Proj./Prog./Dept./Div.: } \\
\begin{array}{l}\text { West Tank Farms Project / } \\
\text { Interim Stabi]ization }\end{array}\end{array}$ & $\begin{array}{l}\text { 6. Cog. Engr.: } \\
\text { R. E. Larson } \\
\text { RE\& }\end{array}$ \\
\hline
\end{tabular}

8. Originator Remarks:

Please sign off on the document by $05 / 17 / 96$ (previously reviewed per EDT 608720).
4. Related EDT No.:

608720

7. Purchase Order No.:

$N / A$

9. Equip./Component No.: N/A

10. System/Bldg./Facility: 241-A-101

11. Receiver Renarks:

12. Major Assm. Dwg. No.: $N / A$

13. Permit/Permit Application Ho.: $N / A$

14. Required Response Date: $05 / 17 / 96$

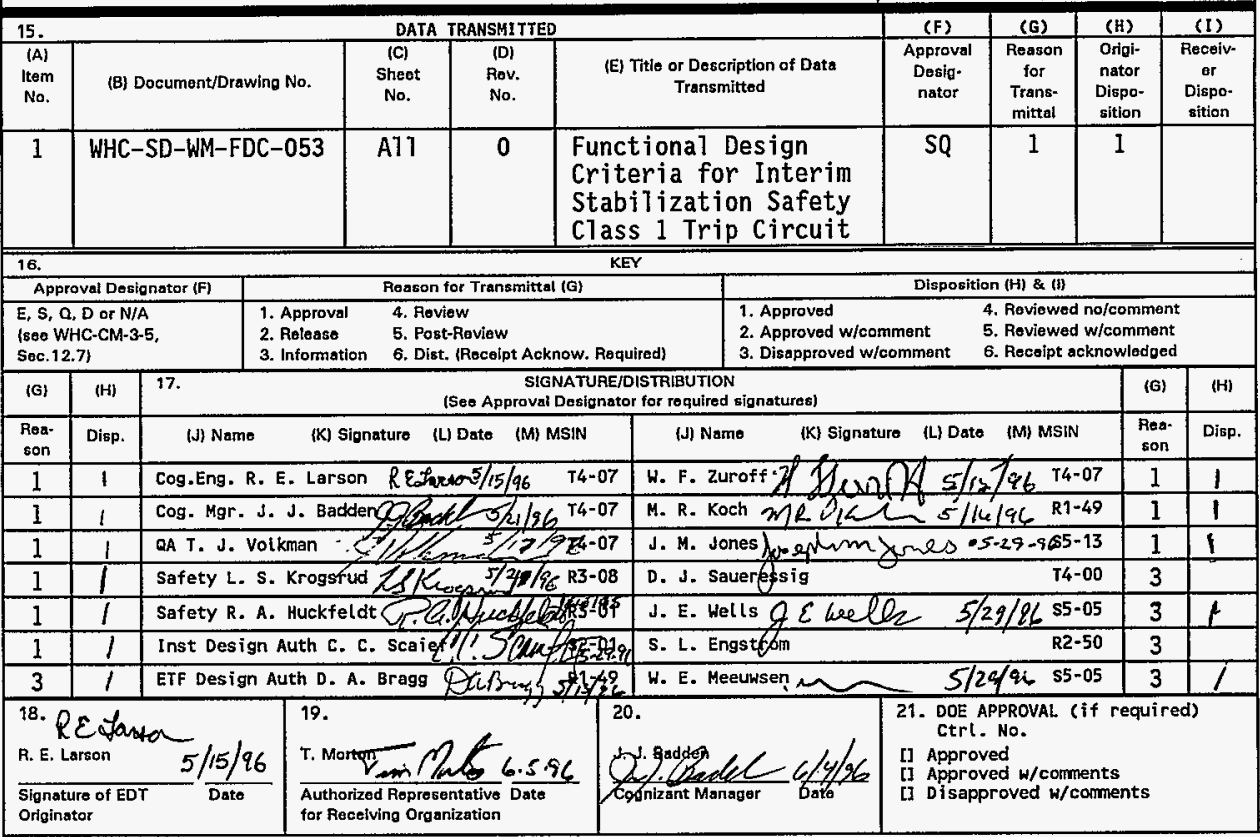

BD-7400-172-2 (04/94) GEF097 


\title{
FUNCTIONAL DESIGN CRITERIA FOR INTERIM STABILIZATION SAFETY CLASS 1 TRIP CIRCUIT
}

\author{
R. E. Larson \\ Westinghouse Hanford Company, Richland, WA 99352 \\ U.S. Department of Energy Contract DE-AC06-87RL10930 \\ 408123 cmis $4 / 10 / 96$ \\ EDT/ECN: EDT-608720 UC: 2030 \\ Org Code: $77420 \quad$ Charge Code: N1737 \\ B\&R Code: EW3120071 Total Pages: $910 \mathrm{kms}$ b/ro/fo
}

Key Words: 241-A-101; Interim Stabilization; Jet Pumping;

Single-She11 Tanks; Safety Shutdown Circuit; Trip Circuit;

Safety Class 1; Sa1twe11 Pumping

Abstract: This Functional Design Criteria document outlines the basic requirements for the Safety Class 1 Trip Circuit.

The objective of the Safety Class 1 Trip Circuit is to isolate the power circuitry to the Class 1 Division 2, Group B or lesser grade electrically fed loads located in the pump pit. The electrically fed load circuits need to have power isolated to them upon receipt of the following conditions; loss of ventilation flow (if an exhaust fan is utilized), dome pressure rise; sensing of flammable gases being released (above a predetermined threshold), and seismic (greater than $0.12 \mathrm{~g}$ acceleration) activity. The two circuits requiring power isolation are the pump and heat trace power circuits.

The Safety Class 1 Trip Circuit will be used to support saltwel1 pumping in SST's containing potentially flammable gas-bearing / gas-producing radioactive waste.

TRADEMARK DISCLAIMER. Reference herein to any specific commercial product, process, or service by trade name, trademark, manufacturer, or otherwise, does not necessarily constitute or imply its endorsenent, recommendation, or favoring by the United States Government or any agency thereof or its contractors or subcontractors.

Printed in the United States of America. To obtain copies of this document, contact: WHC/BCS Document Control Services, P.O. Box 1970, Mailstop H6-08, Richland HA 99352, Phone (509) 372-2420; Fax (509) 376-4989.
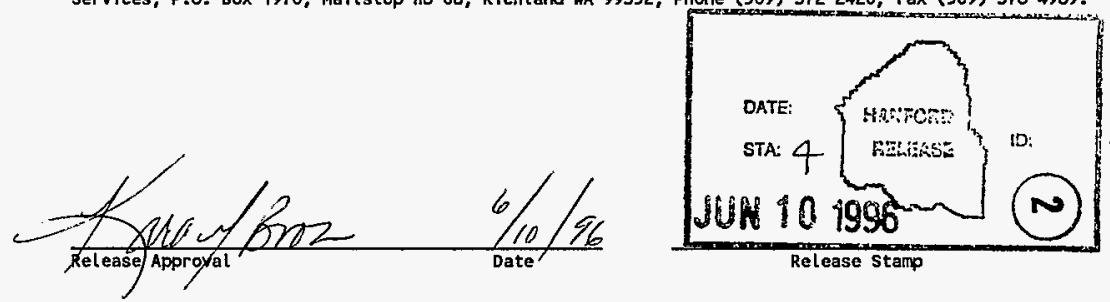

\section{Approved for Public Release}


WHC-SD-WM-FDC-053, Rev. 0

TABLE OF CONTENTS

1.0 SYSTEM DEFINITION ........................... 1 -

1.1 INTRODUCTION ................ . 1 .

1.2 SCOPE . . . . . . . .

1.3 DESIGN BASIS $\ldots \ldots \ldots \ldots \ldots \ldots \ldots \ldots$

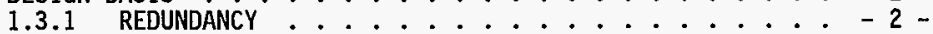

1.3.2 GENERAL ARRANGEMENT $: \ldots \ldots-2-$

1.3 .3 TRIP SYSTEM ............... -2 .

1.3 .4 ENCLOSURE................... 3 . 3 .

1.3.5 SAFETY ................... $4-$

2.0 FUNCTIONAL REQUIREMENTS ............... 5 -

2.1 INTEGRATION ..................... 5 -

2.2 INSTALLATION REQUIREMENTS $\ldots \ldots \ldots \ldots \ldots-5$ -

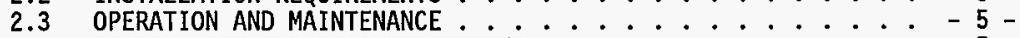

2.4 DESIGN LIFE AND DECOMMISSIONING .......... 5 -

3.0 qUALITY ASSURANCE ................ 5 -

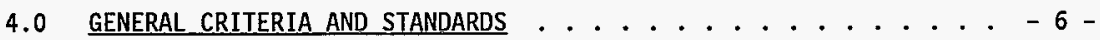

4.1 U.S. DEPARTMENT OF ENERGY ORDERS .......... $\ldots-6$ 4.2 WESTINGHOUSE HANFORD COMPANY/ICF KH $\ldots \ldots \ldots \ldots-6-$

4.3 OTHER PERTINENT DOCUMENTS ............ . . 7 -

4.4 APPLICABLE STANDARDS AND CODES ........... $7-$

5.0 FIGURES ........................ 8 -

FIGURE 1 - PRELIMINARY SCHEMATIC DIAGRAM ......... - 8 - 
WHC-SD-WM-FDC-O53, Rev, 0

\subsection{SYSTEM DEFINITION}

\subsection{INTRODUCTION}

The objective of the Safety Class 1 Trip Circuit is to isolate the power circuitry to the Class 1 Division 2, Group B or Tesser grade electricaliy fed loads located in the pump pit. All control/instrument circuits located in the pump pit (that are not intrinsically safe devices) shall have intrinsically safe barrier relays installed for the circuits (relays located on the jet pump skid). The electrically fed load circuits need to have power isolated to them, upon receipt of the following conditions; loss of ventilation flow (if an exhaust fan is utilized), dome pressure rise; sensing of flammable gases being released (above a predetermined threshold), and seismic (greater than $0.12 \mathrm{~g}$ acceleration) activity. The two circuits requiring power isolation are the pump and heat trace power circuits.

The Safety Class 1 Trip Circuit will be used to support saltwell pumping in SST's containing potentially flammable gas-bearing / gas-producing radioactive waste.

Once the Safety Class 1 Trip Circuit device is installed and operational, future saltwel1 pumping operations on flammable or potentially flammable gas tanks will use this device. The first tank to have the Safety Class 1 Trip Circuit device installed on it is tank A-101.

\subsection{SCOPE}

The Safety Class 1 Trip Circuit system automatically functions (upon loss of an input signal) by isolating power to the electrically fed loads (Class 1 Division 2, Group B or lesser grade) in the pump pit (the pump power and heat trace circuits). The Safety class 1 Trip circuit actuates on inputs from the flammable gas monitor, dome pressure and portable ventilation systems, as required. In addition, the trip circuit actuates upon a loss of power and/or on a failure of an input signal (all inputs are fail safe).

The trip circuit system incorporates the redundancy, and single failure criteria required for a Safety Class 1 component (system). The trip circuit equipment is mounted on a structure that will fail (tip over) during a seismic event $(>0.12 \mathrm{~g})$ or when impacted by a missle. Upon structural failure/missle event the unit actuates the shutdown circuit, via automatic isolation of the Safety Class 1 Trip device control power circuit. A manual reset is required to re-energize the Safety Class 1 Trip device control power circuit.

Redundant inputs are received from the portable ventilation (as required), flammable gas monitoring and dome pressure systems. The input contacts are connected in series so that any one contact can automatically shutdown the power to the pump and heat trace circuits. The shutdown function (for each of the two power circuits to be interrupted) wi 71 be accomplished by the use of redundant contactors connected in series. 
Subsequent to a shutdown when normal operating parameters have been restored, the contactors will require manual action to be reset.

A11 external contacts (input devices) shall be individually wired back through terminal block(s) housed within the Safety Class 1 Trip Circuit panels. Subsequently, if any input devices are determined not to be required, then that specific input can be bypassed by jumpering the input terminals. The panel shall provide space to house relays and/or other devices for the dome pressure input signals.

\subsection{DESIGN BASIS}

The design shall be based upon the following specified criteria, the standard design criteria documents, nationally recognized standards and codes identified in Section 4.0 (e.g., ANSI/NFPA, 1996).

\subsubsection{REDUNDANCY}

The safety function of the Safety Class 1 Trip Circuit system is to mitigate a potential accident scenario (offsite dose consequences $>0.5 \mathrm{rem})$. To assure the Safety Class 1 Trip Circuit system functions properly redundant components are required. The input signal devices to the Safety Class 1 Trip Circuit system shall be redundant to ensure if a single component failure occurs it doesn't prevent the Safety Class 1 Trip circuit system from functioning.

\subsubsection{GENERAL ARRANGEMENT}

The Safety Class 1 Trip Circuit system shall be located in the vicinity of the saltwell jet pumping skid. Cables from the Safety Class 1 Trip Circuit system panels to the input signal devices sha11 be routed in the above grade cable protectors or conduit to ensure mechanical damage to cables doesn't occur. The pump power cable and the heat trace power cables will be routed from the jet pump skid terminal/connection box to the Safety Class 1 Trip Circuit system contactors and then to the loads.

\subsubsection{TRIP SYSTEM}

The Safety Class 1 Trip Circuit system design shal1 incorporate redundancy and physical independence of channels.

The Safety Class 1 Trip Circuit system and each of its redundant items shall fail in a safe state, following a component or channel failure, or loss of power.

The Safety C1ass 1 Trip Circuit system shall consist of two identical, redundant trains. The Safety Class 1 Trip Circuit system panels shail meet the following criteria: 
The trip circuit shall have an input signal from each of the flammable gas monitors (two units).

The trip circuit shall have input signals from the portable ventilation system, as required.

The trip circuit shall have input signals from the dome pressure rise (differential pressure) sensors (two units).

The trip circuit shall be capabie of shutting down due to an seismic event or being struck by a missle.

The trip circuit shall be capable of functioning automatically, and provided with manual trip and manual reset features.

Safety Class 1 Trip Circuit systems could be installed at any tank farm with single-shell tanks while the tank is undergoing saltwell pumping activities. This suggests the following criteria:

The Safety Class 1 Trip Circuit system shall be able to interface with the existing configuration at any single-shell tank which will be pumped.

To the extent practicable, the Safety Class 1 Trip Circuit system shall be designed such that replacement parts are readily available (off-the-shelf) and easily and quickly installed.

The Safety Class 1 Trip Circuit system shall incorporate provisions to facilitate maintenance, inspection, and testing.

The Safety Class I Trip Circuit system shall have signalling devices (indicating lamps) to indicate the operational condition of the control pane] [Power Available (green) and Trip Circuit Functional (Blue) lights].

\subsubsection{ENCLOSURE}

The Safety Class 1 Trip Circuit system shall be designed to allow for installation in an unsheltered area of any single-shell tank farm.

The Safety Class 1 Trip Circuit system shall be able to function in the local environment at the Hanford tank farms. Ambient conditions can be considered to range from -29 to $49^{\circ} \mathrm{C}\left(-20\right.$ to $\left.120^{\circ} \mathrm{F}\right)$ with winds up to $144 \mathrm{kph}(90 \mathrm{mph})$. The relative humidity ranges from 5 to $100 \%$. Rain, snow, sleet, hail, blowing dust and sand, and lightning strikes are all possible occurrences. National Electrical Manufacturers Association (NEMA, 1985) $3 R$ ( $4 X$ if $3 R$ is unavailable) enclosures shall be employed to deal with these conditions. 
WHC-SD-WM-FDC-053, Rev. 0

\subsubsection{SAFETY}

In accordance with Public Law 101-510 ("Wyden Bi11") (U.S. Congress, 1991), Tank 241-A-101 has been evaluated with respect to the criteria for Watch List Tanks, and is currently listed on two watchlists: Flammable Gas and Organics.

Specific restrictions and controls are placed on activities involving this tank and others due to their classification as Watch List Tanks: all operations are performed in compliance with Operating Specifications for Watch List Tanks, OSD-T-151-00030. SaTtwell pumping, an essential part of the tank stabilization process, is not currentiy authorized in singleshe11 flammable gas tanks. Programmatic efforts are in progress to take the actions necessary to authorize saltwell pumping in Tank 241-A-101. Specificaliy, a safety assessment is being written, which will establish controls by which the tank can be safely pumped.

Recently, a hazard analysis was performed in conjunction with the draft Safety Assessment for Salt We11 Jet Pumping in Tank 241-A-101... ("Safety Assessment")(LANL, 1996). Because of the potential radiation dose resulting from a postulated severe accident involving deflagration/ detonation and dome collapse, the critical structures, systems and components to be used in conjunction with jet pumping activities in flammable gas tanks must satisfy the criteria for Safety Class Items as stated in DOE Order 6430.1A, General Desian Criteria (U.S. DOE, 1989). This determination results from evaluating the potential accident consequences in accordance with the WHC Safety Analysis Manual (WHC, 1995). The Safety Assessment also stipulates that continuous controls on saltwell pumping operations be imposed to limit the potential for initiation of a gas deflagration/ detonation resulting from a release of flammable gas and introduction of an ignition source due to saltwell pumping and associated activities.

The Safety Class 1 Trip Circuit system discussed in this Functional Design Criteria document is intended to implement the protective requirements (Controls) imposed in the Safety Assessment. The Safety Class 1 Trip Circuit system will be near Tank 241-A-101 during saltwel1 pumping, hence the equipment shall be designed, fabricated, erected and tested in accordance with DOE $6430.1 \mathrm{~A}$ criteria for Safety Class Items, as discussed above. Without adding risk to saltwell pumping operations, the Safety Class 1 Trip Circuit system will help to enable the safe initiation of saltwell pumping in potentially flammable gas bearing/producing waste in single-she11 tank 241-A-101. The Safety Class 1 Trip Circuit system is to isolate the power circuitry to the Class 1 Division 2, Group B or lesser grade electrically fed loads located in the pump pit. This classification complies with the Interim Safety Bas is documentation for Sing Te-She11 Tank Farms, the Safety Analysis Document (LANL) and with the safety classification of the existing equipment.

The following safety criteria does not apply to the project;

- Criticality

- Shielding

- Contamination Control 
WHC-SD-WM-FDC-O53, Rev. 0

\subsection{FUNCTIONAL REQUIREMENTS}

\subsection{INTEGRATION}

The Safety Class 1 Trip Circuit panels shall be designed to interface with the Flammable Gas Monitors (FGMs), the portable ventilation skid (as required) and the dome pressure monitoring devices. The power circuit isolation devices shall be designed to interface with the power circuits originating from the saltwell jet pump skid.

\subsection{INSTALLATION REQUIREMENTS}

The Safety Class 1 Trip Circuit system shall be installed near the jet pump skid. Exact placement of the Safety Class 1 Trip Circuit system shall be accomplished by the field crews. The equipment shall be rack mounted on a unistrut (or similar) frame. Precast concrete footings (with embedded unistrut) shall be placed in the tank farm where the equipment is to be located. The equipment frame shall be bolted up to the concrete footings (using shear bolts). The design of the frame/mounting details shall include the necessary hardware to ensure that the equipment fails in a safe condition during a seismic or missle event.

\subsection{OPERATION AND MAINTENANCE}

The Safety Class I Trip Circuit system shall be an automatic operating device (reference Figure 1) and shall be manually reset subsequent to a trip.

\subsection{DESIGN LIFE AND DECOMMISSIONING}

The design life expectancy of the Safety Class 1 Trip Circuit system panels is five years. The design life easily exceeds the longest anticipated saltwell pumping campaign by approximately two years. The trip system panels will be removed when the saltwell pumping campaign on the tank being pumped is completed. The trip system panels will be removed from the tank farm. If the trip system is not planned to be used for another saltwell pumping campaign the equipment will be excessed.

\subsection{QUALITY ASSURANCE}

Quality Assurance activities for all contractors involved in the design, procurement, construction, and testing of the trip device shall be formulated and executed as per direction of a "Letter of Instruction," identifying the $Q A$ requirements. The following requirements shall be addressed;

* Design data and design decisions are documented and traceable.

* The design and design criteria are adequately supported by the prepared plans and specifications. 
WHC-SD-WM-FDC-O53, Rev. 0

* The design meets the design criteria.

* Construction is performed in accordance to the design.

* The testing confirms the adequacy of the design, the quality of construction and procured components, operability, maintainability, availability, and reliability.

* The Safety Class equipment dedication process paperwork is completed.

\subsection{GENERAL CRITERIA AND STANDARDS}

4.1 U.S. DEPARTMENT OF ENERGY ORDERS

U.S. DOE, 1989, General Design Criteria, DOE Order 6430.1A, U.S. Department of Energy, Washington, D.C.

\subsection{WESTINGHOUSE HANFORD COMPANY/ICF KH}

ICF KH, 1994a, Preparation and Control of Engineering and Fabrication Drawings, "ICF KH A/E STD, GG-DWG-01", ICF KH, Richland, Washington.

ICF KH, 1994b, Design Loads for Facilities, "ICF KH A/E STD, GC-LOAD-01", ICF KH, Richland, Washington.

ICF KH, 1994c, Design and Installation of Expansion Anchors, "ICF KH A/E STD, GC-ANCH-OI", ICF KH, Richland, Washington.

Westinghouse, 1993a, Hanford Site Tank Farm Facilities Interim Safety Basis, WHC-SD-WM-ISB-001, Westinghouse Hanford Company, Richland, Washington.

Westinghouse, 1996a, Standard Engineering Practices, WHC-CM-6-1, Westinghouse Hanford Company, Richland, Washington.

Westinghouse, 1996b, Qual ity Assurance Manual, WHC-CM-4-2, Westinghouse Hanford Company, Richiand, Washington.

Westinghouse, 1996c, Safety Analysis Manual, WHC-CM-4-46, "Chapter 9.0, Safety $\mathrm{Cl}$ assification of Structures, Systems and Components", Westinghouse Hanford Company, Richland, Washington.

Operating Specifications for Single-Shell Waste Storage Tanks, OSD-T-151-00013. (Latest revision).

Operating Specifications for Miscellaneous Facilities, OSD-T-151-00015. (Latest revision)

Operating Specifications for Watch List Tanks, OSD-T-151-00030. (Latest revision)

Dougherty, L. F., Single Shell Tanks Interim Operational Safety Requirements, WHC-SD-WM-OSR-005, Rev. 0, June 1993. 
WHC-SD-WM-FDC-O53, Rev. 0

Graves, R. D., Topical Report on Flammable Gases in Non-Burping Waste Tanks, WHC-SD-WM-SARR-015, Rev. 0, JuTy 1994.

\subsection{OTHER PERTINENT DOCUMENTS}

LANL, 1996, A Safety Assessment for Saltwell Jet Pumping Operations in Tank 241-A-101: Hanford Site, Richland, Washington, WHC-SD-WM-SAD-034, Rev. 0, Los Alamos National Laboratory, Los Alamos, New Mexico, April 15, 1996.

\subsection{APPLICABLE STANDARDS AND CODES}

ANSI/NFPA, 1996, National Electrical Code, ANSI/NFPA 70, American National Standards Institute, Washington, D.C. / National Fire Protection Agency, Boston, Massachusetts.

NEMA, 1985, Enclosures for Electrical Equipment (1000 Volts Maximum), NEMA 250-1985, National Electrical Manufacturers Association, Washington, District of Columbia.

In addition to the above standard, applicable "National Consensus" codes, and standards developed by such organizations as ASTM, ANSI, ISA, NEMA and IEEE shal1 be used in the design phase as determined by the organization responsible for operating the equipment. The latest edition of all codes, standards and manuals shall be used. 


\subsection{FIGURES}

\section{FIGURE 1 - PRELIMINARY SCHEMATIC DIAGRAM}

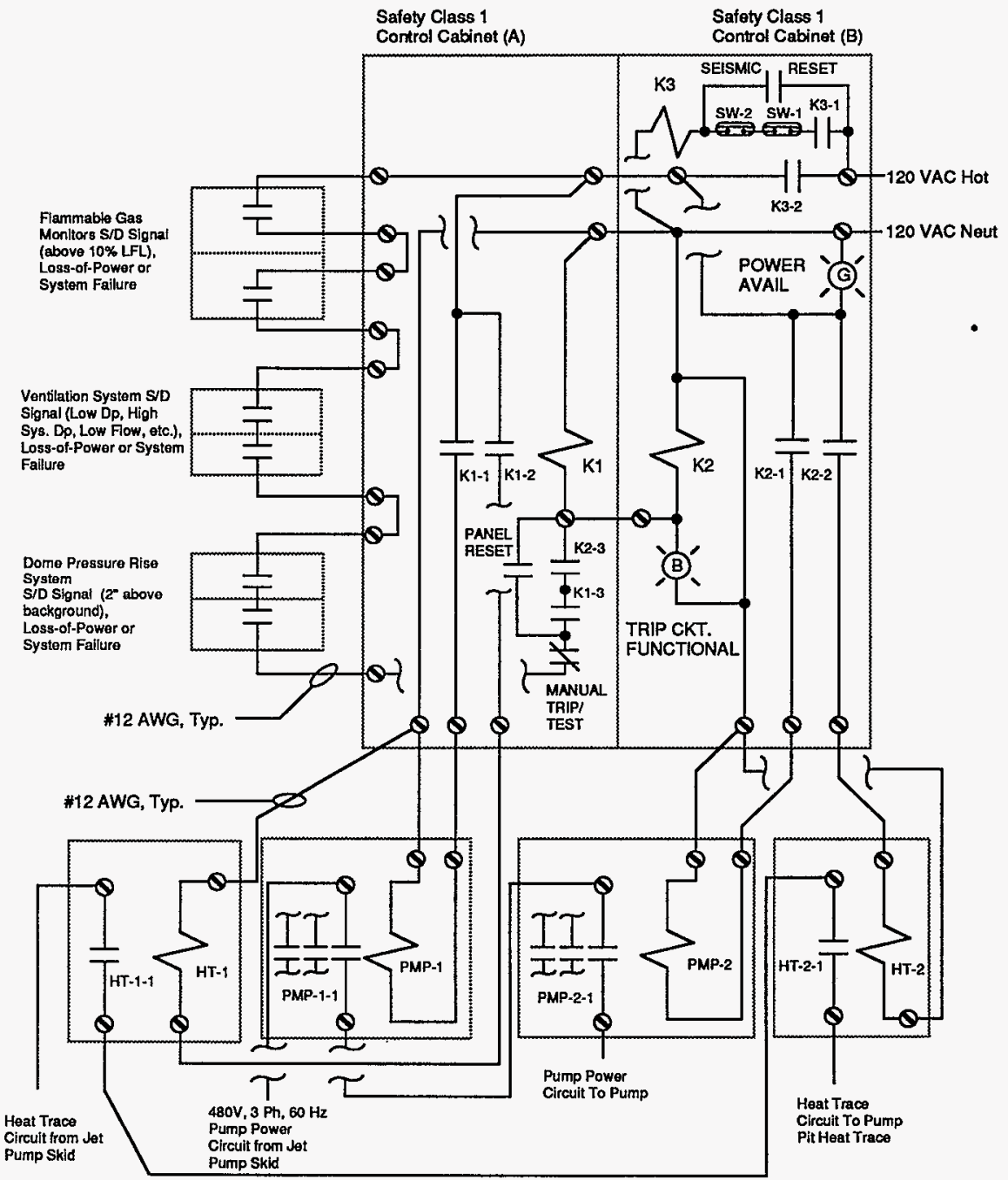

